\title{
STRUKTUR DAN KOMPOSISI JENIS MANGROVE DESA BONEA DAN KODIRI, KABUPATEN MUNA, SULAWESI TENGGARA
}

\author{
Mangrove Composition and Structure in Bonea and Kodiri Village, \\ Muna Regency, Southeast Sulawesi
}

\author{
Rochmady \\ Program Studi Budidaya Perairan, Sekolah Tinggi Ilmu Pertanian Wuna Raha \\ Jl. Jend. Gatot Subroto No.- Km. 7 Lasalepa, Raha, Muna Sulawesi Tenggara \\ Phone+62853 4388 0383; e-mail srochmady@gmail.com / rochmady@stipwunaraha.ac.id
}

\begin{abstract}
ABSTRAK
Kondisi ekosistem mangrove di desa Kodiri dengan kondisi baik, karena upaya pengelolaan yang telah dilakukan masyarakat adat secara swadaya. Mangrove di desa Bonea tergolong rusak, karena tingginya tingkat pemanfaatan khususnya pengambilan kayu bakar. Penelitian bertujuan untuk menganalisis struktur dan komposisi vegetasi mangrove di desa Bonea kecamatan Lasalepa dan desa Kodiri kecamatan Lohia. Parameter Kerapatan Relatif, Penutupan Relatif, Penutupan Relatif Jenis dan Indeks Nilai Penting (INP) digunakan sebagai indikator untuk menggambarkan struktur dan komposisi vegetasi mangrove. Penelitian dilakukan pada bulan Juni sampai bulan Desember 2014 bertempat di pesisir desa Bonea dan desa Kodiri. Analisis data dilakukan di Laboratorium Perikanan STIP Wuna Raha. Pengamatan vegetasi mangrove menggunakan metode kombinasi garis lurus (line transect) dan berpetak sebanyak 3 (tiga) titik pengamatan pada setiap lokasi. Titik pengamatan ditentukan secara sengaja (purposive), berdasarkan keterwakilan kodisi vegetasi mangrove yang dikaji, sehingga terdapat 6 jalur dan 18 petak pengamatan pada dua lokasi. Data vegetasi mangrove dianalisis secara deskriptif-kualitatif. Hasil penelitian, ditemukan vegetasi mangrove di desa Bonea didominasi Ceriops tagal dan Rhizophora apiculata. Penutupan relatif jenis kategori rusak dan kerapatan jenis kategori jarang. Vegetasi mangrove Desa Kodiri di dominasi Rhizophora apiculata, Soneratia alba, Bruguera sexangula, Rhizophora stylosa, Soneratia caseolaris, Bruguera gymnorhiza, dan Avicenia marina. Nilai penutupan relatif jenis kategori baik dan kerapatan relatif jenis kategori jarang.
\end{abstract}

Kata kuncí. Vegetasi mangrove, Kodiri, Bonea, Kabupaten Muna Sulawesi Tenggara.

\begin{abstract}
Mangrove ecosystem conditions in the Kodiri village is quite good, because management efforts that have been carried out by non-indigenous people. Mangrove in Bonea village as classified damaged, due to the high levels of utilization, especially fuelwood. The study aims to analyze the structure and composition of mangrove vegetation in the Bonea village Lasalepa subdistricts and Kodiri villages Lohia subdistrict. Density relative parameter, Covered relatif and Importance Value Index (IVI) is used as an indicator to determining the structure and composition of mangrove vegetation. Research conducted in June to December 2014 in the coastal of Bonea villages and Kodiri villages. Data analysis was carried out in the laboratory of Fisheries STIP Wuna Raha. Observations mangrove vegetation using a combination method of straight-line (line transect) and quadratic transect as much as 3 point of observation at each location. Point of observation is defined deliberately (purposive), based on the representation of mangrove vegetation conditions are examined, so that there are 6 lanes and 18 pieces of observations on two locations. Mangrove vegetation data were descriptively-qualitative analyzed. The results of this found mangrove vegetation in Bonea village dominated Ceriops tagal and Rhizophora apiculata. Relatif covered is broke condition category and relatif density is rare category. Mangrove vegetation in Kodiri village dominated Rhizophora apiculata, Soneratia alba, Bruguera sexangula, Bruguera stylosa, Soneratia caseolaris, Bruguera gymnorhiza, and Avicenia marina. Relatif covered is good condition category and density relatif is rare category.
\end{abstract}

Keywords. Mangrove vegetation, Bonea, Kodiri, Muna Regency, Southeast Sulawesi. 


\section{Pendahuluan}

Istilah mangrove merujuk pada ekosistem lahan basah, dipengaruhi pasang surut di zona intertidal daerah tropis dan subtropis. Mangrove berasal dari kata "Mangue" Afrika Barat, Senegal, Gambia, dan Guinea. Abad ke-XV, bangsa Spanyol mengadopsi kata "Mangle" dan "Manglar" lalu menyebarkannya (Macintosh \& Ashton, 2002). Mangrove (Inggris) merupakan derivasi kata Mangue dalam Portugal yakni komunitas tumbuhan, yang berarti hutan (Onrizal, 2008). Selain itu, mangrove juga merujuk pada komunitas jenis Rhyzopora (Hidayatullah \& Pujiono, 2014). Dalam perkembangannya, istilah "mangrove" digunakan untuk menyebut jenis tumbuhan, dalam hal ini termasuk tumbuh di pinggiran vegetasi mangrove seperti Barringtonia dan Pes-caprae (Noor, et al., 1999). Lembaga Pangan Dunia (FAO) mengartikan mangrove sebagai vegetasi yang memiliki fungsi-fungsi sosial ekonomi dan lingkungan (ekologis) (Kustianti, 2011).

Vegetasi mangrove khas memperlihatkan adanya pola zonasi, yang terkait erat dengan tipe tanah (lumpur, pasir atau gambut), terbuka terhadap hempasan gelombang, salinitas serta pengaruh pasang surut (Noor, et al., 1999). Daerah mangrove merupakan wilayah subur baik daratan maupun perairannya, karena adanya transportasi nutrien dari pasang surut (Gunarto, 2004) (Noor, et al., 1999). Dengan demikian, mangrove dikenal sebagai salah satu sumberdaya wilayah pesisir dengan produktifitas tinggi (Putz \& Chan, 1986). Oleh karena itu, kawasan mangrove memiliki peran strategis baik secara ekologis, maupun ekonomis (Hidayatullah \& Pujiono, 2014). Di Indonesia, areal yang selalu digenangi walaupun pada saat pasang rendah umumnya didominasi oleh Avicennia alba atau Sonneratia alba. Areal yang digenangi pasang sedang didominasi jenis Rhizophora. Areal yang digenangi hanya pada saat pasang tinggi, lebih ke daratan, umumnya didominasi jenis Bruguiera dan Xylocarpus granatum, sementara areal yang digenangi pada saat pasang tertinggi (hanya beberapa hari sebulan) umumnya didominasi Bruguiera sexangula dan Lumnitzera littorea.

Pemanfaatan nilai ekonomi hasil mangrove secara tidak terkendali telah berdampak negatif terhadap kondisi fisik mangrove (Fauzi, 2004). Seiring pertambahan jumlah penduduk, intensitas eksploitasi mangrove ikut meningkat baik diambil kayu maupun organisme asosiasinya. Akibatnya mangrove di beberapa tempat mengalami kerusakan dan penurunan kondisi, luasan dan komposisi, seperti di daerah Pulau Tobea dan pesisir Lambiku (Rochmady, 2011). Di desa Wabintingi dan Labone Kabupaten Muna, pemanfaatan mangrove terkait langsung dengan aktivitas perikanan masyarakat dalam menopang kebutuhan ekonomi sehari-hari mereka. Seperti mengambil kayu, menangkap ikan, udang, kepiting, mengumpulkan kerang dan budidaya maupun berbagai kegiatan perikanan lainnya (Rakhfid \& Rochmady, 2014). Selain itu, kerusakan mangrove terkait erat dengan perkembangan pembangunan beberapa tahun terakhir yang cenderung menempatkan wilayah pesisir sebagai daerah strategis. Dalam hal ini aktivitas perikanan, industri, permukiman, pariwisata (Fauzi, 2004).

Sulawesi Tenggara memiliki mangrove sekitar 74.348,82 ha. Sekitar 21.723,55 ha dilaporkan dengan kondisi rusak dan sekitar 1.984,49 ha kondisi rusak berat (BP-DAS Sampara, 2007). Dari beberapa kabupaten di Sulawesi Tenggara, Kabupaten Muna tergolong memiliki mangrove terbesar. Ini didukung garis pantai sebesar $\pm 519 \mathrm{~km}$ tersebar di 181 pulau kecil (DKP Muna, 2008). Luas mangrove Kabupaten Muna sebesar 27.204,55 ha, sekitar 22.175,47 ha kondisi baik dan sisanya 5.029,08 ha kondisi rusak. Hal ini dukung oleh laporan Dinas Kehutanan Kabupaten Muna yang mencatat terjadi penurunan luasan mangrove berkisar 200-400 ha setiap tahun, dimana dalam kurun waktu lima tahun terakhir laju degradasi mangrove lebih tinggi (Aqsa, 2010).

Mangrove di desa Kodiri seluas 10 ha, memiliki daya dukung terhadap produksi perikanan cukup tinggi. Hal ini terlihat dari nilai ekonomi hasil manfaat lansung yang ditaksir sebesar Rp.858.878.876,- per tahun atau sebesar Rp.85.887.888,- per ha per tahun. Sementara mangrove di desa Bonea sebesar 270 ha nilai ekonomi manfaat langsung ditaksir sebesar Rp.158.226.314,- per tahun atau sebesar Rp.586.023,- per ha per tahun (Rakhfid \& Rochmady, 2014). Jika dikelola secara bijaksana, keberadaan vegetasi mangrove merupakan aset yang relatif memiliki nilai ekonomi cukup besar dalam mendorong pembangunan suatu wilayah, khususnya dalam menopang pembangunan ekonomi lokal maupun nasional (Fauzi, 2004).

Dengan demikian, peranan mangrove dirasakan semakin penting dan strategis, selain karena nilai manfaat ekonomi yang menguntungkan, juga karena dampak ekologis merugikan akibat hilangnya vegetasi mangrove (Rahman, 2008). Beberapa sebab kerusakan vegetasi mangrove tersebut khususnya yang terjadi di Kecamatan Napabalano (Rochmady, 2011), Kecamatan Lasalepa, Kabupaten Muna lebih disebabkan oleh aktivitas pemanfaatan berlebih, berupa pengambilan hasil kayu (Rakhfid \& Rochmady, 2014), pencemaran, maupun akibat tsunami dan sedikit akibat dari intrusi air laut (Giri, et al., 2008) maupun sebab-sebab lainnya. Oleh karena itu, penting untuk menganalisis struktur dan komposisi jenis 
vegetasi mangrove di kedua lokasi tersebut. Pengukuran vegetasi dan survey lapangan menggunakan kriteria baku kerusakan mangrove Kepmen LH Nomor 201/2004 dengan berpedoman pengenalan mangrove Indonesia (Noor, et al., 1999).

Penelitian bertujuan untuk menganalisis struktur dan komposisi vegetasi mangrove di Desa Kodiri, Kecamatan Lohia dan Desa Bonea, Kecamatan Lasalepa, Kabupaten Muna. Penelitian diharapkan memberi informasi mengenai struktur dan komposisi vegetasi mangrove dalam pengambilan kebijakan pengelolaan dan pemanfaatan sumberdaya alam mangrove khususnya di Desa Kodiri Kecamatan Lohia dan Desa Bonea Kecamatan Lasalepa, Kabupaten Muna kepada instansi terkait, khususnya Dinas Kelautan dan Perikanan dan Dinas Kehutanan Kabupaten Muna.

\section{Bahan dan Metode}

Penelitian dilaksanakan selama 6 bulan, yakni bulan April sampai dengan September 2014, berlokasi di Desa Bonea, Kecamatan Lasalepa dan Desa Kodiri, Kecamatan Lohia, Kabupaten Muna, Sulawesi Tenggara (Gambar l). Penentuan titik pengamatan ditetapkan secara sengaja (purposive), berdasarkan keterwakilan kondisi vegetasi mangrove yang dikaji, yakni mewakili kondisi vegetasi mangrove dekat sungai dan jauh dari sungai di kedua lokasi. Analisis data dan pengamatan lanjutan terkait identifikasi jenis mangrove dilakukan di Laboratorium Perikanan, Sekolah Tinggi Pertanian Wuna, Raha.

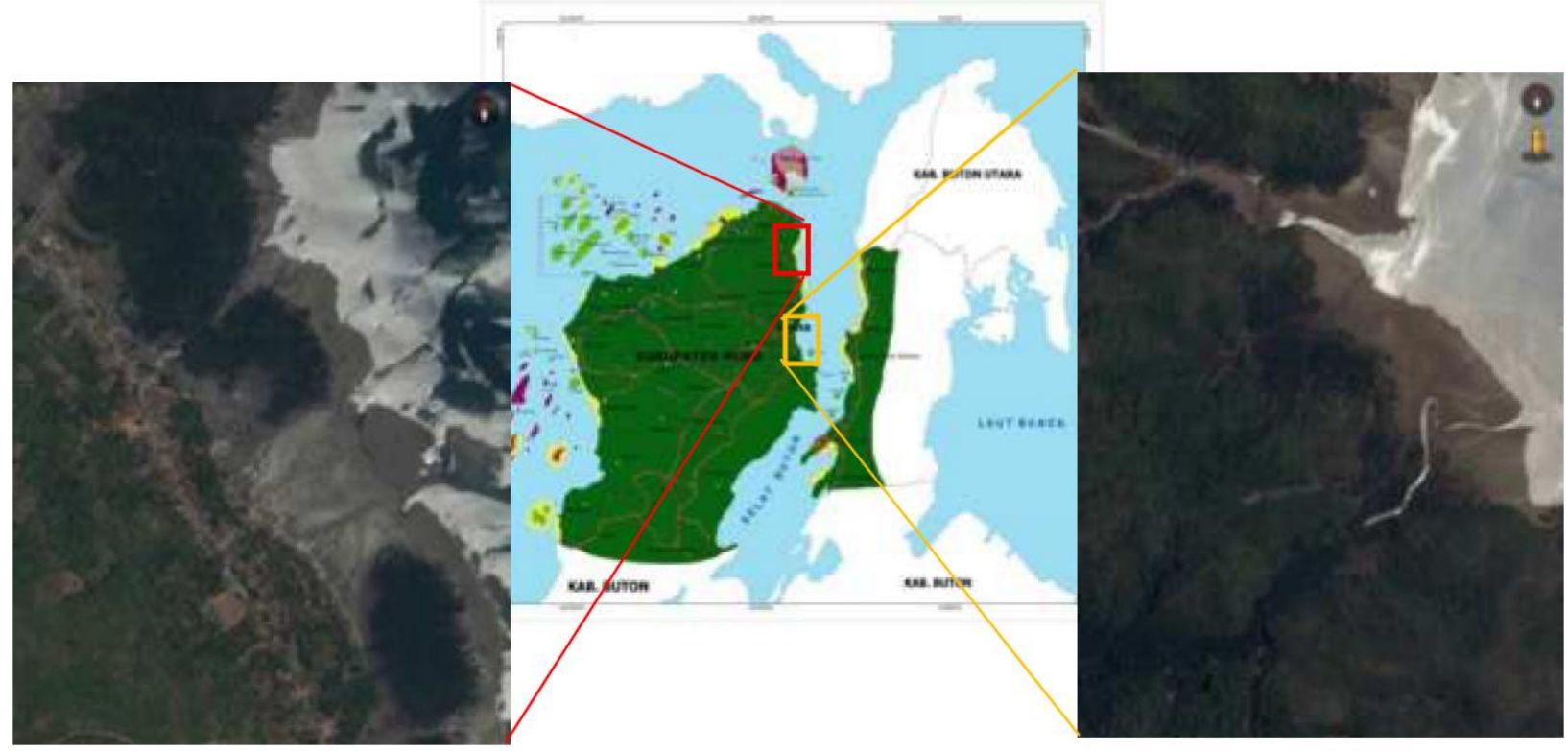

Gambar 1 Lokasi penelitian di pesisir Bonea Kecamatan Lasalepa (kiri) dan pesisir Kodiri, Kecamatan Lohia (kanan), Kabupaten Muna

Bahan dan peralatan yang digunakan selama penelitian terdiri atas sampel herbarium mangrove berupa daun, bunga dan buah, kertas karton, rol meter $100 \mathrm{~m}$, tali rafiah, kamera digital, parang, galah, kompas, peta kerja, personal used, buku lapangan, buku pedoman inventaris dan identifikasi mangrove (Noor, et al., 1999), serta alat tulis menulis lainnya.

Metode pengukuran dan pengambilan data vegetasi menggunakan metode garis lurus atau transek garis (line transek plot). Pada lokasi penelitian ditentukan stasiun pengambilan contoh berdasarkan keterwakilan lokasi. Pengambilan data lapangan vegetasi mangrove hanya meliputi tegakan pohon. Setiap stasiun pengambilan contoh, ditarik garis tegak lurus dari arah pantai sepanjang $100 \mathrm{~m}$, dan di sepanjang garis tersebut diletakkan secara sengaja plot pengamatan yang berukuran $10 x 10 \mathrm{~m}$ pada titik $0 \mathrm{~m}, 50 \mathrm{~m}$ dan $100 \mathrm{~m}$ sebagai plot pengamatan (Gambar 2). Kemudian dilakukan pengamatan dan pengukuran diameter batang pohon (DBH) (tegakan) di atas pangkal akar, pengamatan jenis mangrove dan jumlah tegakan pohon (Kementerian Lingkungan Hidup, 2004). Transek garis dibuat sebanyak 3 (tiga) titik mewakili muara sungai bagian depan, tengah dan belakang. Hal tersebut didasarkan pada pertimbangan kondisi vegetasi mangrove yang relatif tebal dan disesuaikan dengan pertimbangan-pertimbangan lapangan. 
Untuk lokasi dengan kondisi vegetasi mangrove yang relatif rusak, pengukuran vegetasi dengan peletakan transek yang mewakili kondisi yang ada di lokasi tersebut.

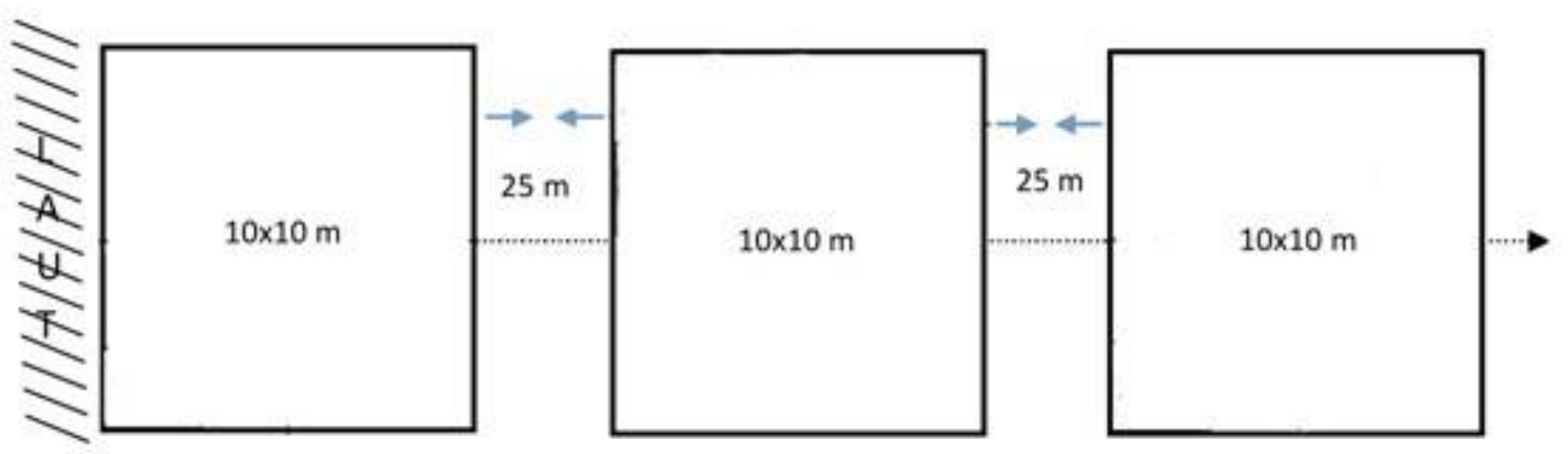

Gambar 2 Desain plot pengamatan kombinasi metode jalur dan garis berpetak

Data hasil pengamatan dan pengukuran vegetasi mangrove yang diperoleh dianalisis secara deskriptif untuk menjelaskan kondisi vegetasi mangrove di Desa Kodiri dan Desa Bonea berdasarkan kriteria baku mutu vegetasi mangrove (Kementerian Lingkungan Hidup, 2004). Analisis vegetasi untuk menentukan kondisi ekologis mangrove menggunakan beberapa jenis perhitungan, yaitu kerapatan jenis, frekuensi jenis, luas area penutupan, Indeks Nilai Penting (INP) dari tiap jenis, dan indeks keanekaragaman. Untuk mencari nilai INP digunakan tiga perhitungan, yaitu nilai kerapatan tiap jenis, nilai frekuensi tiap jenis, dan nilai dari penutupan tiap jenis. berikut ini:

Variabel Penelitian. Kerapatan Spesies. Kerapatan jenis dihitung dengan menggunakan rumus

$$
D i=n i / A
$$

Keterangan: Di merupakan kerapatan spesies i, ni merupakan jumlah total tegakan dari spesies i, dan A merupakan luas total area pengambilan contoh.

Selanjutnya menghitung nilai kerapatan relatif spesies (RDi).

$$
\mathrm{RDi}=(\mathrm{ni} / \Sigma \mathrm{n}) \times 100
$$
berikut:

Penutupan Spesies. Penutupan spesies dihitung dengan menggunakan rumus penutupan spesies

$$
\mathrm{Ci}=\boldsymbol{\Sigma} \mathrm{BA} \times \mathrm{A}
$$

Keterangan: BA merupakan nilai dari $\pi \mathrm{DBH}^{2} / \mathrm{A}$, $\pi$ merupakan konstanta, $\mathrm{DBH}$ merupakan diameter batang pohon spesies i, dan A merupakan luas total area pengambilan contoh. Selanjutnya dihitung nilai penutupan relatif spesies (RCi).

$$
\mathrm{RCi}=(\mathrm{Ci} / \Sigma \mathrm{C}) \times 100
$$

Frekuensi Spesies. Frekuensi spesies dihitung dengan menggunakan rumus sebagai berikut:

$$
\mathrm{Fi}=\mathrm{Pi} / \mathbf{\Sigma} \mathrm{P}
$$

Keterangan: Fi merupakan frekuensi spesies i, Pi merupakan jumlah plot dimana ditemukan jenis i, dan P merupakan jumlah total plot. Selanjutnya menghitung frekuensi relatif spesies (RFi).

$$
\mathrm{RFi}=(\mathrm{Fi} / \Sigma \mathrm{F}) \times 100)
$$

Indeks Nilai Penting. Indeks nilai penting digunakan untuk memberi gambaran mengenai pengaruh atau dominansi suatu jenis mangrove dalam ekosistem tersebut. Indeks nilai penting memiliki 
kisaran antara 0-300 (Fachrul, 2008). Oleh karena mangrove yang amati dan diukur dalam penelitian ini hanya mangrove tingkat pohon, maka indeks nilai penting yang dihitung merupakan jumlah kerapatan relatif spesies (RDi), frekuensi relatif spesies (RFi), dan penutupan relatif spesies (RCi):

$$
\mathrm{INP}=\mathrm{RDi}+\mathrm{RFi}+\mathrm{RCi}
$$

Indeks Keanekaragaman. Indeks keanekaragaman $\left(\mathrm{H}^{-}\right)$digunakan untuk mengetahui pengaruh faktor-faktor lingkungan, terhadap komunitas maupun untuk mengetahui keadaan suksesi atau stabilitas ekosistem mangrove. Indeks keanekaragaman dihitung menggunakan pendekatan keanekaragaman jenis Shannon-Wienner (1963) dengan kriteria jika $H^{-}>3$ menunjukkan keanekaragaman spesies yang tinggi, $\mathrm{H}^{\prime}$ menacapai $1 \leq H^{-} \leq 3$ menunjukkan keanekaragaman spesies yang sedang, dan $H^{-}<3$ menunjukkan keanekaragaman spesies yang sedikit atau rendah. Persamaan Shannon-Wienner tersebut adalah sebagai berikut:

$$
\mathbf{H}^{\prime}=-\sum \frac{\mathrm{ni}}{\mathrm{N}} \log \frac{\mathrm{ni}}{\mathrm{N}}
$$

Keterangan: H' merupakan indeks keanekaragaman Shannon-Wienner, ni merupakan jumlah individu dari suatu jenis i dan $\mathrm{N}$ merupakan jumlah total individu dari seluruh jenis.

Analisis Data. Seluruh data variabel yang diperoleh terkait vegetasi mangrove dihitung secara kuantitatif untuk mendapatkan nilai dari kerapatan relatif, penutupan relatif, frekuensi relatif, indeks nilai penting dan indeks keanekaragaman setiap lokasi menggunakan baku mutu kerusakan mangrove Kementrian LH. Hasil perhitungan tersebut kemudian dianalisis secara deskriptif.

\section{Hasil dan Pembahasan}

Hasil pengamatan dan identifikasi jenis mangrove di 3 (tiga) sublokasi di pesisir Desa Bonea, Kecamatan Lasalepa secara keseluruhan ditemukan sebanyak 4 spesies mangrove. Sementara di pesisir Desa Kodiri, Kecamatan Lohia secara keseluruhan ditemukan sebanyak 8 spesies mangrove. Berdasarkan panduan pengenalan mangrove (Noor, et al., 1999) dan klasifikasi (Tomlinson, 1994), spesies-spesies yang didapat di Desa Bonea termasuk dalam famili Rhizoporacea (Tabel 1). Sementara spesies-spesies yang didapat di Desa Kodiri termasuk dalam 4 famili, yakni 3 famili kelompok mayor dan 1 famili kelompok asosiasi, secara berturut-turut adalah Avicenniaceae, Rhizoporaceae, Soneratiaceae dan Malvacea. (Tabel 1). Namun demikian, pada kedua lokasi tersebut ditemukan beberapa famili di luar dari vegetasi mangrove yang dilalui transek, seperti spesies Nypa fruticans Wurmb. dari famili Arecaceae dan Ipomoea pes-caprae (L.) Sweet dari famili Convolvulaceae.

Tabel l Komposisi mangrove di pesisir Desa Bonea, Kecamatan Lasalepa, dan Desa Kodiri Kecamatan Lohia,

\begin{tabular}{|c|c|c|c|}
\hline Lokasi & Komponen & Famili & Spesies \\
\hline Bonea & Mayor & Rhizoporacea & $\begin{array}{l}\text { Ceriops tagal (Perr.) C.B.Rob. } \\
\text { Bruguera gymnorrhiza (L.) Lamk } \\
\text { Bruguera hainessii C.G. Rogers } \\
\text { Rhizopora apiculata (Bl.) }\end{array}$ \\
\hline \multirow[t]{3}{*}{ Kodiri } & Mayor & $\begin{array}{l}\text { Avicenniaceae } \\
\text { Rhizoporaceae }\end{array}$ & $\begin{array}{l}\text { Avicenia marina (Forsk.) Vierh. } \\
\text { Bruguera gymnorhiza (L.) Lamk. Ex Savigny } \\
\text { Rhizopora stylosa Griff. } \\
\text { Bruguera sexangula (Lour.) Poir. } \\
\text { Rhizopora apiculata (Bl.) }\end{array}$ \\
\hline & & Soneratiaceae & $\begin{array}{l}\text { Soneratia alba J.E. Smith } \\
\text { Soneratia caseolaris (L.) Engl. }\end{array}$ \\
\hline & Asosiasi & Malvacea & Hibiscus tiliaceus L. \\
\hline
\end{tabular}
Kabupaten Muna, Sulawesi Tenggara 
Spesies mangrove maupun tingkat famili mangrove yang ditemukan di pesisir Desa Kodiri cenderung lebih banyak dibandingkan dengan jumlah spesies mangrove yang ditemukan di pesisir Desa Bonea. Namun demikian, kedua lokasi tersebut relatif hampir sama dengan jumlah jenis mangrove yang ditemukan di Golo Sepang, Kecamatan Boleng, Kabupaten Manggarai Barat, sebanyak 10 spesies dari 5 famili, 9 dari 10 spesies yang ditemukan termasuk mangrove sejati sementara sisanya merupakan jenis mangrove asosiasi (Hidayatullah \& Pujiono, 2014). Namun bila dibandingkan dengan yang ditemukan di Pulau Jemaja, Kabupaten Kepulauan Anambas cenderung lebih kecil. Di Pulau Jemaja ditemukan sebanyak 17 spesies mangrove yang terdiri dari 9 jenis mangrove sejati, 3 jenis mangrove ikutan dan 5 jenis mangrove asosiasi (Fuady, et al., 2013).

Struktur komunitas mangrove di Bonea, Kecamatan Lasalepa, terdiri atas spesies Ceriops tagal dan Rhizopora apiculata famili Rhiziporaceae mendominasi seluruh plot pengamatan untuk kategori tegakan pohon, kemudian disusul spesies Bruguera gymnorrhiza dan Bruguera hainessii (Tabel 1). Berdasarkan kriteria kerusakan mangrove Kementerian Lingkungan Hidup dapat diketahui spesies Ceriops tagal dengan kerapatan individu sebesar 2.867 ind per ha tergolong sangat padat dengan tingkat penutupan sebesar 31\% tergolong rusak. Kemudian spesies Rhizopora apiculata, dengan kerapatan individu sebesar 1.433 ind per ha tergolong sedang, tingkat penutupan sebesar $46 \%$ tergolong baik. Selanjutnya spesies Bruguera gymnorrhiza tingkat kerapatan individu sebesar 300 ind per ha tergolong jarang, tingkat penutupan sebesar 10\% tergolong rusak. Spesies Bruguera hainessi dengan kerapatan individu sebesar 200 ind per ha tergolong jarang dengan tingkat pernutupan sebesar 13\% tergolong rusak (Gambar 3).

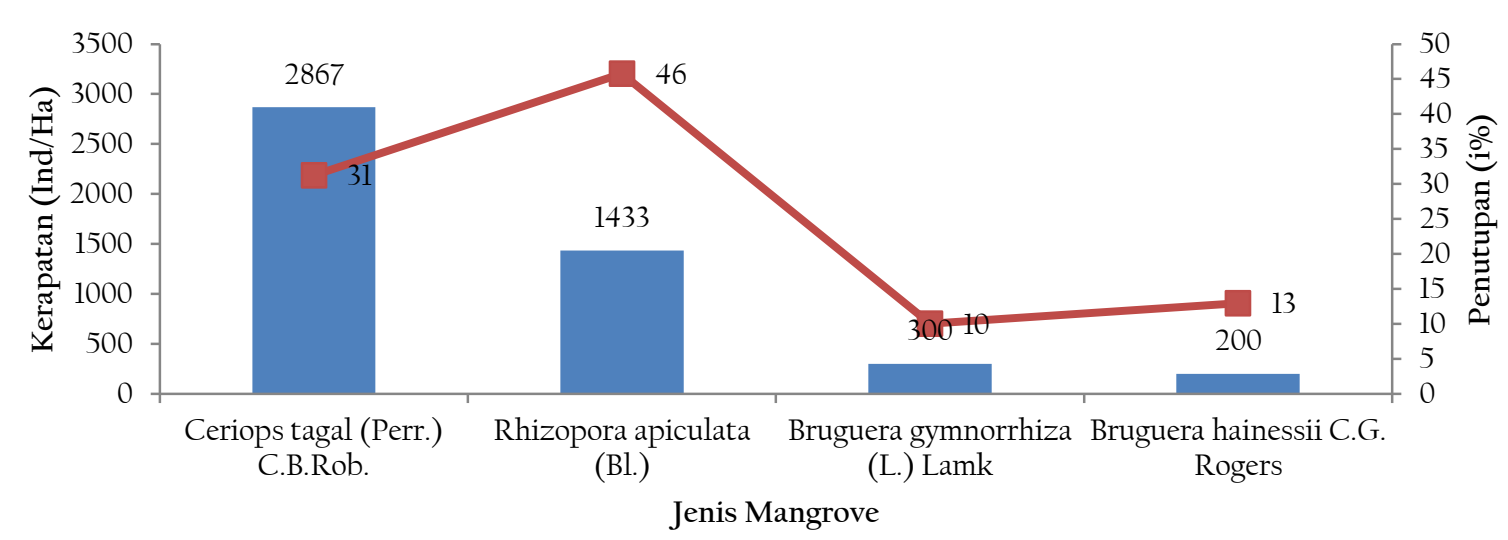

Gambar 3 Kerapatan jenis dan penutupan relatif spesies mangrove di Desa Bonea, Kecamatan Lasalepa, Kabupaten Muna, Sulawesi Tenggara

Menurut Chapman, jenis vegetasi mangrove famili Rhizoporaceae dicirikan substrat tanah (sedimen) dengan kesuburan tinggi yang telah terbentuk lama (Indawan, et al., 2012). Hal yang sama ditemukan di Golo Sepang, Kecamatan Boleng, Kabupaten Manggarai Barat. Kelompok tumbuhan famili tersebut memiliki bentuk adaptasi pada kondisi lingkungan tertentu sehingga mendukung pertumbuhan dan perkembangannya (Hidayatullah \& Pujiono, 2014). Sejalan dengan itu, diduga substrat pesisir Desa Bonea kaya akan nutrient yang terbawa bersama aliran sungai. Unsur hara yang terbawa bersama aliran sungai terakumulasi pada sedimen, begitu pula dengan unsur hara berasal dari laut (pasang-surut) menjadikan pesisir Bonea relatif subur. Selain itu, diduga kesuburan tersebut merupakan hasil dari perombakan sisa-sisa penebangan pohon mangrove.

Struktur komunitas mangrove di pesisir Desa Kodiri, Kecamatan Lohia, terdiri atas spesies Rhizopora apiculata, Soneratia alba, dan Bruguera sexangula mendominasi hampir seluruh plot pengamatan, kemudian disusul spesies Bruguera stylosa, Soneratia caseolaris, Bruguera gymnorrhiza, Avicenia marina dan Hibiscus tiliaceus (Tabel l). Berdasarkan tingkat kerapatan dan penutupan menurut kriteria Kementeria Lingkungan Hidup (2004) dapat diketahui spesies Rhizopora apiculata memiliki kerapatan sebesar 3.233 ind per ha tergolong sangat padat dengan tingkat penutupan sebesar $40 \%$ tergolong rusak, spesies Soneratia alba dengan tingkat kerapatan sebesar 1.633 ind per ha tergolong sangat padat, tingkat penutupan sebesar 18\% tergolong rusak dan spesies Bruguera sexangula dengan tingkat keraparan sebesar 1.367 ind per ha tergolong sedang dengan tingkat penutupan $11 \%$ tergolong rusak (Gambar 4). 


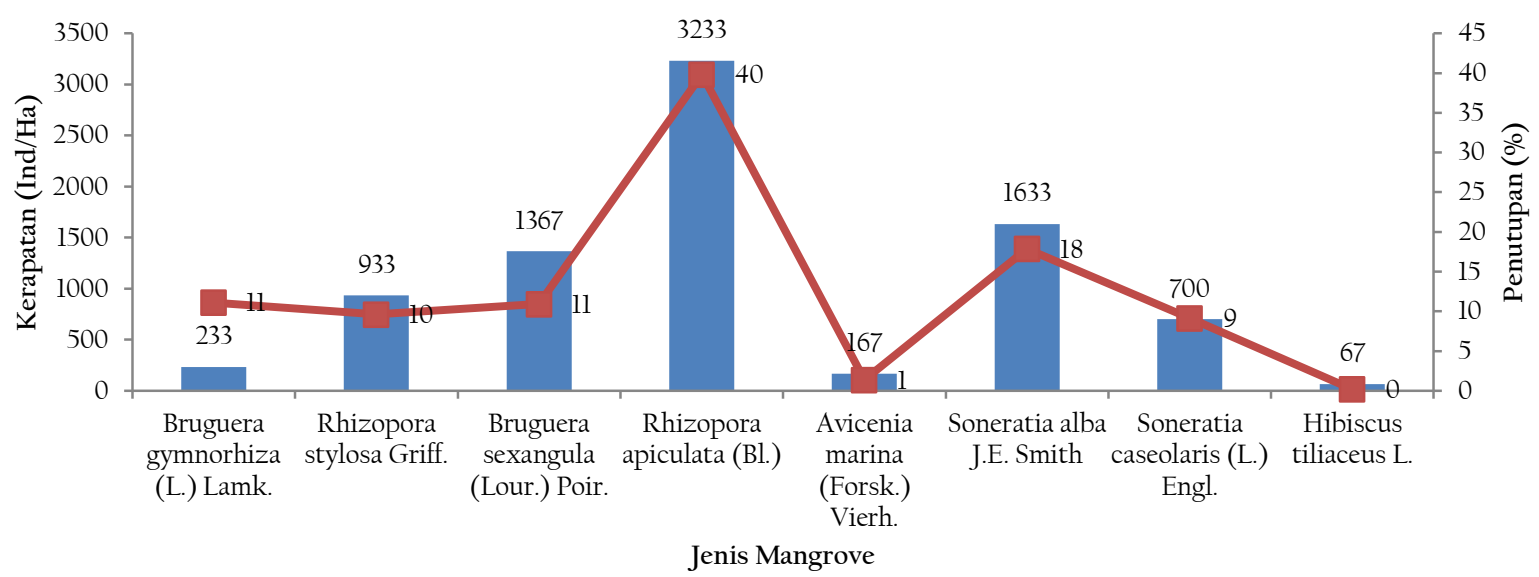

Gambar 4 Kerapatan jenis dan penutupan relatif spesies mangrove di Desa Kodiri, Kecamatan Lohia, Kabupaten Muna, Sulawesi Tenggara

Kondisi vegetasi mangrove di pesisir Kodiri relatif berbeda dengan kondisi vegetasi di pesisir Bonea walaupun memiliki tingkat kerapatan individu dan penutupan yang relatif hampir sama. Vegetasi mangrove pesisir Bonea merupakan jenis tegakan anakan, sementara vegetasi mangrove di pesisir Kodiri merupakan jenis tegakan pohon berusia tua. Hal yang sama dilaporkan pada daerah pesisir Kecamatan Lambiku, Kabupaten Muna, penutupan jenis dengan kategori jarang bermakna usia tanaman tua dan rimbun, sehingga mengakibatkan nilai penutupan yang relatif rendah (Rochmady, 2011).

Tingkat keanekaragaman vegetasi mangrove di pesisir Bonea dan Kodiri sebagaimana pada Tabel 2. Dominasi famili Rhizoporaceae di kedua lokasi menunjukkan tingkat keanekaragaman tergolong sedang. Diduga dominasi famili tersebut terkait dengan tingkat kesuburan tanah dan aktivitas pemanfaatan dan umur tanaman. Kesuburan tanah pada pesisir Desa Bonea dan Desa Lohia di duga terkait erat dengan adanya sungai. Keberadaan sungai memiliki peranan penting dalam mensuplai unsur hara, baik dari daratan maupun dari laut. Sirkulasi pasang-surut dan intrusi sedimen dari darat diduga kuat menjadi penyebab tinggi kesburan substrat tanah baik di pesisir Bonea maupun di pesisir Kodiri.

Tabel 2 Regenerasi vegetasi mangrove menurut sublokasi di pesisir Desa Bonea dan Desa Kodiri

\begin{tabular}{llll}
\hline \multirow{2}{*}{ Lokasi } & \multirow{2}{*}{ Sublokasi (plot) } & \multicolumn{2}{c}{ Indeks Keanekaragaman $\left(\boldsymbol{H}^{-}\right)$} \\
\cline { 3 - 4 } & & Nilai & Kategori \\
\hline Bonea & 1 Daerah dekat laut & 1,1113 & Sedang \\
& 2 Daerah pertengahan & 1,3853 & Sedang \\
3 Daerah ke arah darat & 1,4668 & Sedang \\
\multirow{2}{*}{ Kodiri } & 1 Daerah dekat laut & 1,3126 & Sedang \\
& 2 Daerah pertengahan & 1,8357 & Sedang \\
& 3 Daerah ke arah darat & 1,4623 & Sedang \\
\hline
\end{tabular}

Secara visual kondisi vegetasi mangrove di pesisir Desa Bonea memperlihatkan kondisi yang relatif rusak (Gambar 5). Aktivitas pemanfaatan mangrove secara ekstraktif yakni pengambilan kayu bakar secara tidak terkendali ditengarai menjadi salah satu sebab terjadinya perubahan vegetasi mangrove, selain lokasi wilayah pesisir Bonea tempat vegetasi mangrove tumbuh berdekatan dengan pemukiman penduduk. Infomasi yang diperoleh, aktifitas ekstraktif tersebut telah berlangsung lama dengan jumlah pengambil semakin bertambah setiap tahunnya. Dengan demikian, hal ini ditengai berdampak semakin tingginya tekanan terhadap vegetasi mangrove. Hal yang sama dilaporkan oleh Rakhfid et al., (2014) di desa Labone, aktifitas pengambilan kayu bakar telah merambah ke wilayah sekitar desa Labone, ditengarai salah satunya adalah Desa Bonea. 


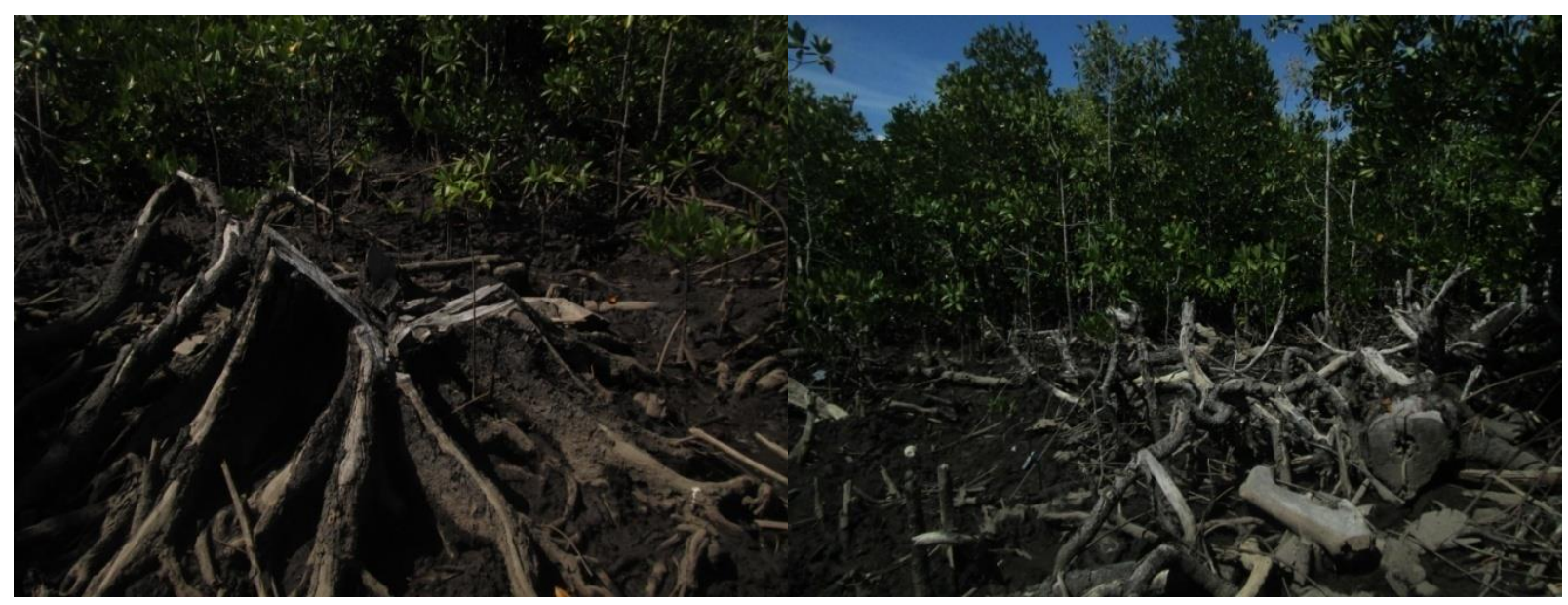

Gambar 5 Kondisi visual mangrove di Desa Bonea, Kecamatan Lasalepa, Kabupaten Muna, Sulawesi Tenggara (Sumber: Foto lapangan, 2013)

Kondisi vegetasi mangrove di pesisir Desa Kodiri memperlihatkan kondisi relatif baik (Gambar 6). Sebagaimana dilaporkan, bahwa bentuk pemanfaatan secara fisik di pesisir Kecamatan Lohia berupa pengambilan ranting dan dahan kering yang telah lapuk, serta pengumpulan kerang, penangkapan ikan, dan udang maupun daun nipa sebagai atap bangunan (Rakhfid \& Rochmady, 2014). Selain itu, bentuk pemanfaatan secara fisik lebih kepada penggunaan keunikan pohon mangrove sebagai tambatan perahu bagi para nelayan sekitar hutan. Bentuk kegiatan pemanfaatan lainnya adalah pengambilan daun nipa yang dijadikan sebagai bahan pembuatan atap.

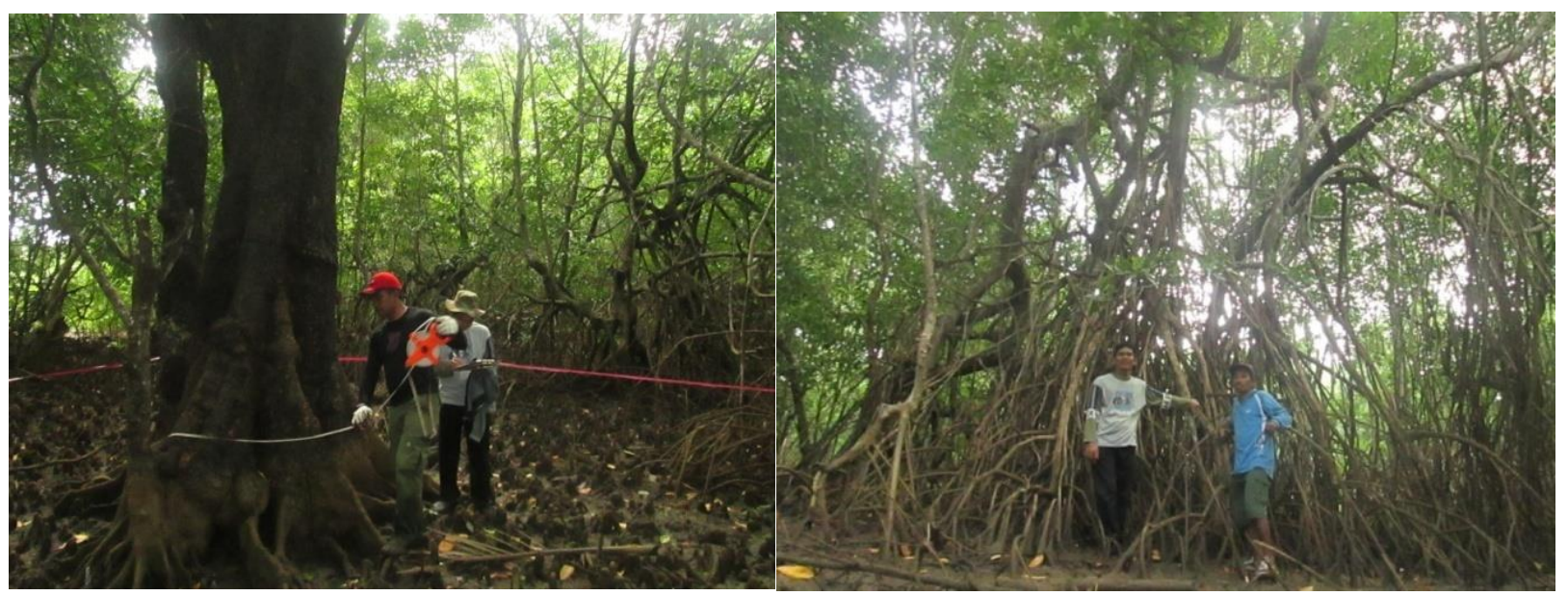

Gambar 6 Kondisi visual mangrove di Desa Kodiri, Kecamatan Lohia, Kabupaten Muna, Sulawesi Tenggara (Sumber: Foto lapangan, 2013)

Pemanfaatan fisik mangrove di Desa Kodiri relatif tidak merusak, yakni mengambil kayu lapuk, tambatan perahu dan pengambilan daun nipa sebagai bahan pembuatan atap bangunan. Pemanfaatan secara biologis, sebagai tempat menangkap ikan, udang, kepiting, maupun kerang-kerangan, mengingat vegetasi mangrove merupakan tempat dengan kandungan nutrien cukup tinggi sehingga memungkinkan organisme laut seperti ikan, udang-udangan termasuk kepiting dan kerang-kerangan relatif melimpah sehingga mampu memberi daya dukung bagi kehidupan organisme laut sekitar vegetasi mangrove (Kustianti, 2011). Diduga bentuk pemanfaatan tersebut belum melampuai daya dukung sumberdaya sehingga kondisi sumberdaya mangrove relatif masih terjaga.

Dengan demikian vegetasi mangrove di Desa Kodiri lebih baik dibanding dengan kondisi mangorve di Desa Bonea. Mangrove di Desa Kodiri relatif tidak terganggu oleh aktivitas manusia (Rakhfid $\&$ Rochmady, 2014). Selain itu, substrat dengan kesuburan tinggi didominansi spesies yang relatif hampir sama dari famili Rhizoporiaceae. Dominasi spesies pada kedua lokasi tersebut merupakan jenis vegetasi 
mangrove yang memiliki toleransi terhadap perubahan salinitas yang dapat tumbuh dengan baik di sepanjang sungai, mulai dari hulu sampai hilir, dan tidak dapat tumbuh pada daerah berkarang (Noor, et al., 1999). Hal ini sebagaimana yang ditemukan di Kawasan Pesisir Pulau Sebatik, Kabupaten Nunukan, Kalimantan Timur (Ardiansyah, et al., 2012), didominasi spesies Soneratia alba, Rhizopora apiculata, Rhizopora mucronata dan Avicenia alba dan di daerah pesisir Desa Pasar Banggi, Kabupaten Rembang (Saputro, et al., 2013), di dominasi spesies Rhizopora mucronata.

Berdasarkan kondisi tersebut, pernyataan adanya penurunan luasan vegetasi mangrove di Kabupaten Muna seakan terkonfirmasi sebagaimana disampaikan oleh BP Das Sampara (2010) dan Aqsa (2010), bahwa terjadi penurunan luasan hutan mangrove di Kabupaten Muna sejak lima tahun terakhir. Namun demikian, pendapat ini mesti ditelusuri lebih jauh oleh karena belum seluruh wilayah pesisir Kabupaten Muna dengan vegetasi mangrove diteliti.

\section{Kesimpulan}

Berdasarkan hasil dan pembahasan, disimpulkan bahwa vegetasi mangrove di desa Bonea tergolong rusak, tingkat kerapatan jarang, didominasi vegetasi mangrove jenis Rhizopora apiculata tumbuhan baru. Sementara vegetasi mangrove di desa Kodiri kecamatan Lohia tergolong baik tingkat kerapatan jarang, didominasi oleh vegetasi mangrove jenis Rhizopora apiculata, tumbuhan berusia tua.

\section{Ucapan Terima Kasih}

Terima kasih kepada masyarakat utamanya bapak La Aga, pemerintah kecamatan Lohia dan Lasalepa serta Kepala Desa Kodiri dan Desa Bonea yang memberi izin penelitian. Terima kasih kepada saudara La Ode Hamrudin Momo, SP., M.Sc dan Abdul Rakhfid, S.Pi yang telah membantu dalam melakukan pengukuran dan pengamatan di lapangan.

\section{Daftar Referensi}

Aqsa, M., 2010. Rehabilitasi dan Konservasi Mangrove dalam Menunjang Kawasan Konservasi Laut Daerah (KKLD) Selat Tiworo.

Available at: http://mimpi22.wordpress.com/category/rehabilitasi-dan-konservasi-mangrovesultra/

[Diakses 12 Oktober 2012].

Ardiansyah, W., Pribadi, R. \& Nirwani, S., 2012. Struktur dan Komposisi Vegetasi Mangrove di Kawasan Pesisir Pulau Sebatik, Kabupaten Nunukan, Kalimantan Timur. Volume l (2), pp. 203-215.

BP-DAS Sampara, 2007. Mangrove Propinsi Sulawesi Tenggara. Kendari: BP-DAS Sampara dan Perhutanan Sosial Departemen Kehutanan RI.

DKP Muna, 2008. Laporan Tahunan Statistik Perikanan. Raha: Dinas Perikanan dan Kelautan.

Fachrul, M., 2008. Metode Sampling Bioekologi. Jakarta: PT. Bumi Aksara.

Fauzi, A., 2004. Ekonomi Sumberdaya Alam dan Lingkungan. Teori dan Aplikasi. Jakarta: PT. Gramedia Pustaka Utama.

Fuady, I., Pribadi, R. \& Nirwani, 2013. Struktur komunitas mangrove di Pulau Jemaja, Kabupaten Kepulauan Anambas dan Pulau Liran, Kabupaten Maluku Barat Daya. Volume 2 (2), pp. 94-102.

Giri, C. et al., 2008. Mangrove Forest Distributions and Dynamics (1975-2005) of The Tsunami-Affected Region of Asia. USA: Blackwell Publishing Ltd.

Gunarto, 2004. Konservasi Mangrove Sebagai Pendukung Sumber Hayati Perikanan Pantai. Maros: Balai Riset Perikanan Budidaya Air Payau.

Hidayatullah, M. \& Pujiono, E., 2014. Struktur dan Komposisi Jenis Hutan Mangrove Di Golo SepangKecamatan Boleng Kabupaten Manggarai Barat. Juni, Volume 3, pp. 151-162. 
Indawan, E., Ahmadi, K. \& Novitawati, R. A. D., 2012. Komposisi Mangrove pada Lahan Tercemar BTEX dan Logam Berat. Juni, Volume 14, pp. 212-218.

Kementerian Lingkungan Hidup, 2004. Keputusan Menteri Negara Lingkungan Hidup Nomor 201 Tahun 2004 Tentang Kriteria Baku Dan PedomanPenentuan Kerusakan Mangrove, Jakarta: Kementerian Lingkungan Hidup.

Kustianti, 2011. Manajemen Vegetasi Mangrove. Bogor: IPB Press.

Macintosh \& Ashton, 2002. Review of Mangrove Biodiversity Conservation and Management; The World and Center for Tropical Ecosystems Research (cenTER Aarhus, Denmark: University of Aarhus.

Noor, Y., Khazali, M. \& Suryadiputra, I., 1999. Pedoman Pengenalan Mangrove di Indonesia. 2 ed. Bogor: Wetlands International Indonesian Programe.

Onrizal, 2008. Panduan Pengenalan dan Analisis Vegetasi Hutan Mangrove, Medan: Universitas Sumatera Utara.

Putz, F. E. \& Chan, H. T., 1986. Tree Growth, Dynamic and Productivity in a Mature Mangrove Forest in Malaysia. Amsterdam: Elsiever Scince Publisher B.V..

Rahman, 2008. Koefisien Seret Gaya Gelombang Pada APO dengan Tambahan Gedhek, Makassar: Media Teknik Sipil, Universitas Hasanuddin.

Rakhfid, A. \& Rochmady, 2014. Valuasi Ekonomi Hutan Mangrove di Kabupaten Muna (Studi Kasus Desa Wabintingi Kecamatan Lohia dan Desa Labone Kecamatan Lasalepa). September, Volume 6, pp. 82-104.

Rochmady, 2011. Aspek Bioekologi Kerang Lumpur Anodontia edentula Linnaeus, 1758 (BIVALVIA: LUCINIDAE) di Perairan Pesisir Kabupaten Muna, Makassar: Program Pascasarjana, Universitas Hasanuddin.

Saputro, I., Pribadi, R. \& Pratikto, I., 2013. Kajian Struktur dan Komposisi Vegetasi Mangrove Di Kawasan Pesisir Desa Pasar Banggi, Kabupaten Rembang. Volume 2 (4), pp. 104-110.

Tomlinson, P., 1994. The Botany of Mangrove. New York: Cambridge University Press. 